\title{
Evaluating tree-to-tree competition during stand development in a relict Scots pine forest: how much does climate matter?
}

\author{
Laura Marqués ${ }^{1,2} \oplus$. J. Julio Camarero ${ }^{3} \cdot$ Miguel A. Zavala $^{2} \cdot$ Markus Stoffel $^{4,5,6}$ - Juan A. Ballesteros-Cánovas ${ }^{4,5}$. \\ Cesar Sancho-García ${ }^{7}$ Jaime Madrigal-González ${ }^{4}$
}

Received: 29 March 2020 / Accepted: 19 February 2021 / Published online: 10 March 2021

(c) The Author(s) 2021, corrected publication 2021

\begin{abstract}
Key message Competitive interactions change over time and their influence on tree growth is intensified during drought events in marginal Scots pine populations.

Abstract Competition is a key factor driving forest dynamics and stand structure during the course of stand development. Although the role of neighbourhood competition on stand dynamics has received increasing attention, the response of competition to environmental fluctuations and stand development remains poorly explored. We evaluated changes in competition during stand development in a dry-edge Scots pine relict population located in Central Spain. Typically, tree-to-tree interactions have been investigated through static competition measurements, which usually lack the temporal variation associated to natural forest development and environmental conditions. Here, we assessed how individual and neighbourhood components of competition evolved along a 35-year period, and we related competition dynamics to population structure and drought levels. On six plots, 508 trees were mapped and diameters at breast height (DBH) were measured. Two increment cores were taken from target trees to derive basal area increment (BAI), and neighbourhood was reconstructed back to 1980. Results provide insights into inter-annual variability in competition effects and their role on tree radial growth depending on climatic conditions. From the year 2005 onwards, both individual and neighbourhood components of competition showed a decoupled pattern over time. This effect was particularly pronounced during the extreme drought in 2012, in which the individual component decreased, whereas the neighbourhood component increased. In addition, climatic variability modulated the competition effects during stand development. This approach of evaluating competition dynamics proves to be promising for studying forest stand development and the influence of climate impacts on tree populations subjected to xeric conditions.
\end{abstract}

Keywords Competition effects · Dendroecology $\cdot$ Drought stress $\cdot$ Pinus sylvestris $\cdot$ Stand development $\cdot$ Tree radial growth

Communicated by Vospernik.

Laura Marqués

lauramarqueslopez@gmail.com

1 Department of Environmental Systems Science, Swiss Federal Institute of Technology (ETH Zürich), Universitätstrasse 2, 8092 Zürich, Switzerland

2 Forest Ecology and Restoration Group, Department of Life Sciences, Universidad de Alcalá (UAH), Edificio Ciencias, Campus Universitario, 28871 Alcalá de Henares, Madrid, Spain

3 Instituto Pirenaico de Ecología, (IPE-CSIC), Avda. Montañana, 1005, 50192 Zaragoza, Spain
4 Climate Change Impacts and Risks in the Anthropocene, Institute for Environmental Sciences, University of Geneva, 66 Boulevard Carl Vogt, 1205 Geneva, Switzerland

5 Department of Earth Sciences, University of Geneva, 13 Rue des Maraîchers, 1205 Geneva, Switzerland

6 Department F.-A. Forel for Environmental and Aquatic Sciences, University of Geneva, 66 Boulevard Carl Vogt, 1205 Geneva, Switzerland

7 Department of Applied Mathematics, University of Valladolid, Avenida del Valle Esgueva 6, 47011 Valladolid, Spain 


\section{Introduction}

Competition is a key biotic factor driving stand dynamics (Oliver and Larson 1996; Kunstler et al. 2011) through its influences on light, soil water and nutrients interception (Coomes and Allen 2007; Das et al. 2008). A number of studies have pointed out the effect of competition on tree radial growth (Stadt et al. 2007; Looney et al. 2016; Buechling et al. 2017), as well as its variation along environmental gradients (Cotillas et al. 2009; Linares et al. 2010; Gómez-Aparicio et al. 2011). Different competition indices have often been applied; these indices either used distance-independent metrics at the stand level (Biging and Dobbertin 1995) or distance-dependent indices taking the spatial distribution of trees into account (Canham et al. 2006; McTague and Weiskittel 2016; Tatsumi et al. 2016). Most of these studies have investigated spatial interactions among individual trees using static approaches (Brooker and Callaghan 1998; Coomes and Allen 2007), which lack a temporal component and may be inadequate to represent competitive dynamics over time (Burton 1993; De Luis et al. 1998).

Population dynamics are subjected to their own endogenous demographic processes, which intrinsically vary over time. For instance, increasing tree size and density in a population imply an increase in space filling that may intensify competitive interactions among neighbouring individuals (Yoda et al. 1963; Jump et al. 2017). Furthermore, temporal fluctuations in the environment can modify the interactions between neighbouring tree individuals (Biondi 1996; Travis et al. 2005), thereby affecting their competitive ability (Weber et al. 2008; Sánchez-Salguero et al. 2015; Aakala et al. 2018). Understanding how competition evolves over time is therefore essential to evaluate how forest functioning might be compromised under changing environmental conditions.

The degree to which the outcome of competition is either symmetric or asymmetric plays a fundamental role for plant population structure (Pacala and Weiner 1991; Keddy 2001). When light is a limiting resource, tree-totree competition often shows size asymmetry, with larger trees having a competitive advantage over smaller trees. In contrast, symmetric competition has been related to limiting below-ground resources (Schwinning and Weiner 1998) since root competition may not be associated with tree size (Berntson and Wayne 2000). Size-asymmetric competition may become increasingly symmetric at later stages of stand development (Masaki et al. 2006; Pothier 2017), possibly as a result of decreasing soil water availability (Pretzsch and Dieler 2010). Thus, competitive effects can be decomposed into two main aspects: i.e. (i) the size of target trees, and (ii) the influences from neighbouring trees. Quantifying the relative contribution of each component over the course of stand development is therefore crucial to properly assess the importance of competition under climatic fluctuations.

Tree species compete intensively for light, but also for soil water in drought-prone Mediterranean forests (Zavala et al. 2000) where ongoing climate change is already affecting ecosystem functioning negatively by reducing productivity and increasing mortality (Schröter et al. 2005; Doblas-Miranda et al. 2017). Intraspecific competition has been particularly observed when the abiotic stress gradient is driven by water resources (Maestre et al. 2009). Increased aridity may promote more intense tree-to-tree competitive interactions than in other, non-water limited areas (Zavala and Bravo de la Parra 2005), particularly in tree populations subjected to xeric conditions (Hampe and Petit 2005; Sánchez-Salguero et al. 2015). One of the most drought-vulnerable species in Mediterranean forests is Scots pine (Pinus sylvestris L.) (Martínez-Vilalta et al. 2008; Camarero et al. 2015a, b). Scots pine is a widely distributed conifer with its southwestern limit of distribution on the Iberian Peninsula (Barbero et al. 1998), where natural populations are highly fragmented (Ruiz-Labourdette et al. 2012). Further, interactions between climate, stand structure and competition have also been reported for Scots pine (Gómez-Aparicio et al. 2011; Primicia et al. 2016; Marqués et al. 2018), with more negative effects observed in dryer areas (Vilà-Cabrera et al. 2011; González de Andrés et al. 2017), as well as drought(Camarero et al. 2015b) and competition-induced mortality (Ruiz-Benito et al. 2013).

In this study, we use a tree-ring width dataset of Scots pine stands sampled in Central Spain with the aim to evaluate the role of competition as a driver of population dynamics over a 35-year period that exhibits a warming trend and includes several intense drought episodes. We analyse the abovementioned two aspects of competition: the individual component of competition, associated with target tree size, and the neighbourhood component of competition, relative to the effect exerted by neighbouring trees. The focus of the study is on the temporal variation of competition effects. Specifically, we address the following questions: (i) What is the effect of target tree size (individual component) and neighbouring trees (neighbourhood component) on tree growth through time? and (ii) To what extent does climatic variability modulate such components of competition in a dry-edge Scots pine population? We hypothesize that competition will be strongly tied to structure dynamics in the sense that increasing space filling would lead to progressively stronger competitive interactions among individuals. Additionally, competition will be modulated in time by climatic variability (droughts in this case), although with different intensities over each of the components of competition (target tree size, neighbouring effects). These research 
questions will help us to better understand how competitive interactions vary over time and are altered by climate fluctuations.

\section{Materials and methods}

\section{Study area and species}

The study was carried out in a managed pine forest located in the central-northern part of the Iberian Peninsula at an elevation of $875 \mathrm{~m}$ a.s.1. $\left(4^{\circ} 14^{\prime} \mathrm{W}, 41^{\circ} 19^{\prime} \mathrm{N}-\right.$; Fig. 1$)$. The dominant species is maritime pine (Pinus pinaster Ait.), followed by Scots pine, although black pine (Pinus nigra Arnold), and several shrub species [Helichrysum stoechas (L.) Moench or Thymus mastichina L.] are also present in the area. Scots pine is located at the lower altitudinal and latitudinal limit of the trees species distribution where water availability becomes the main constraint of forest growth (dry-edge, Hampe and Petit 2005), forming relict and scattered populations. As documented in the historical forest management archives, the Scots pine population established naturally after the last clear-cut in the 1960s and no further management interventions have been carried out since. Likewise, neither has individual natural mortality been registered in the archives nor observed in the field. Together, this represents a unique opportunity to study stand development and to reconstruct spatial neighbourhood changes in a dry-edge population of Scots pine. Climate in the area is continental Mediterranean, with cold winters and warm dry summers (Peel et al. 2007). Mean annual temperature is $12^{\circ} \mathrm{C}$ and annual total precipitation ranges from 430 to $450 \mathrm{~mm}$. This forest occupies inland dunes with sandy soils displaying low nutrient content and very low water retention capacity (Gómez-Sanz and Garcia-Viñas 2011).

\section{Climate records}

Mean annual temperature and annual total precipitation records were obtained from the nearest meteorological stations (National Agency for Meteorology in Spain, AEMET): Valladolid ( $4^{\circ} 43^{\prime} \mathrm{W}, 41^{\circ} 39^{\prime} \mathrm{N}, 690 \mathrm{~m}$; located $51 \mathrm{~km}$ northwards) and Segovia ( $4^{\circ} 07^{\prime} \mathrm{W}, 40^{\circ} 57^{\prime} \mathrm{N}, 1002 \mathrm{~m}$; located $50 \mathrm{~km}$ southwards). We computed the associated climatic aridity index (AI) defined in terms of the ratio between precipitation and evapotranspiration (UNEP 1992), as follows: (a)

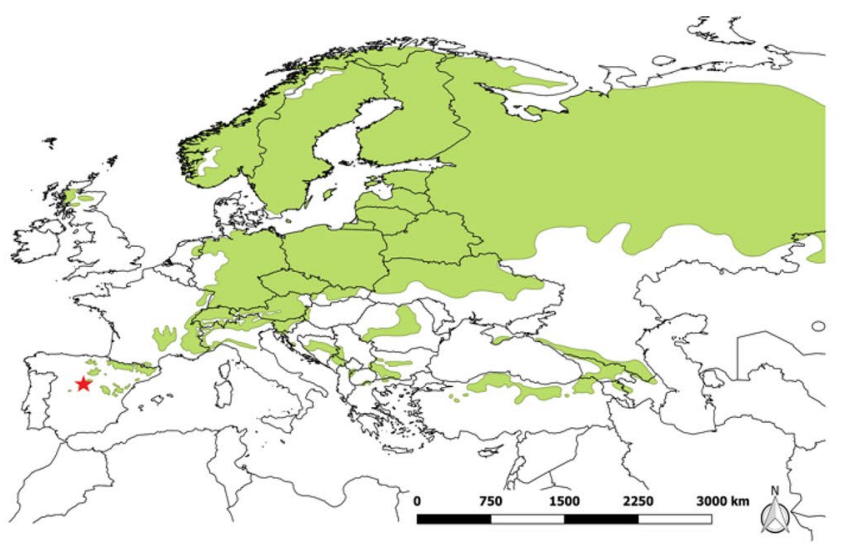

(c)

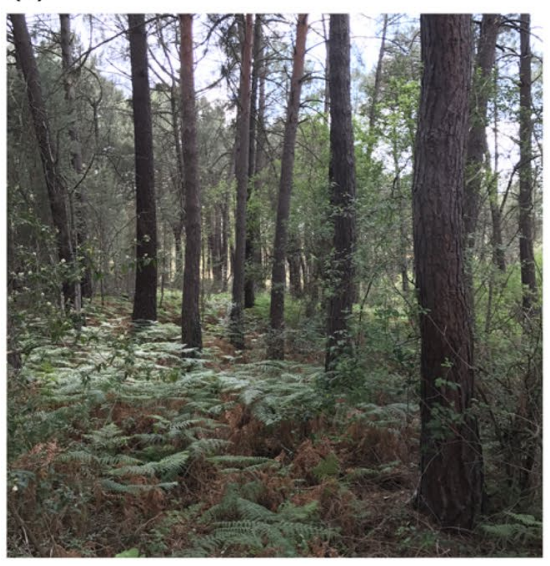

(b)
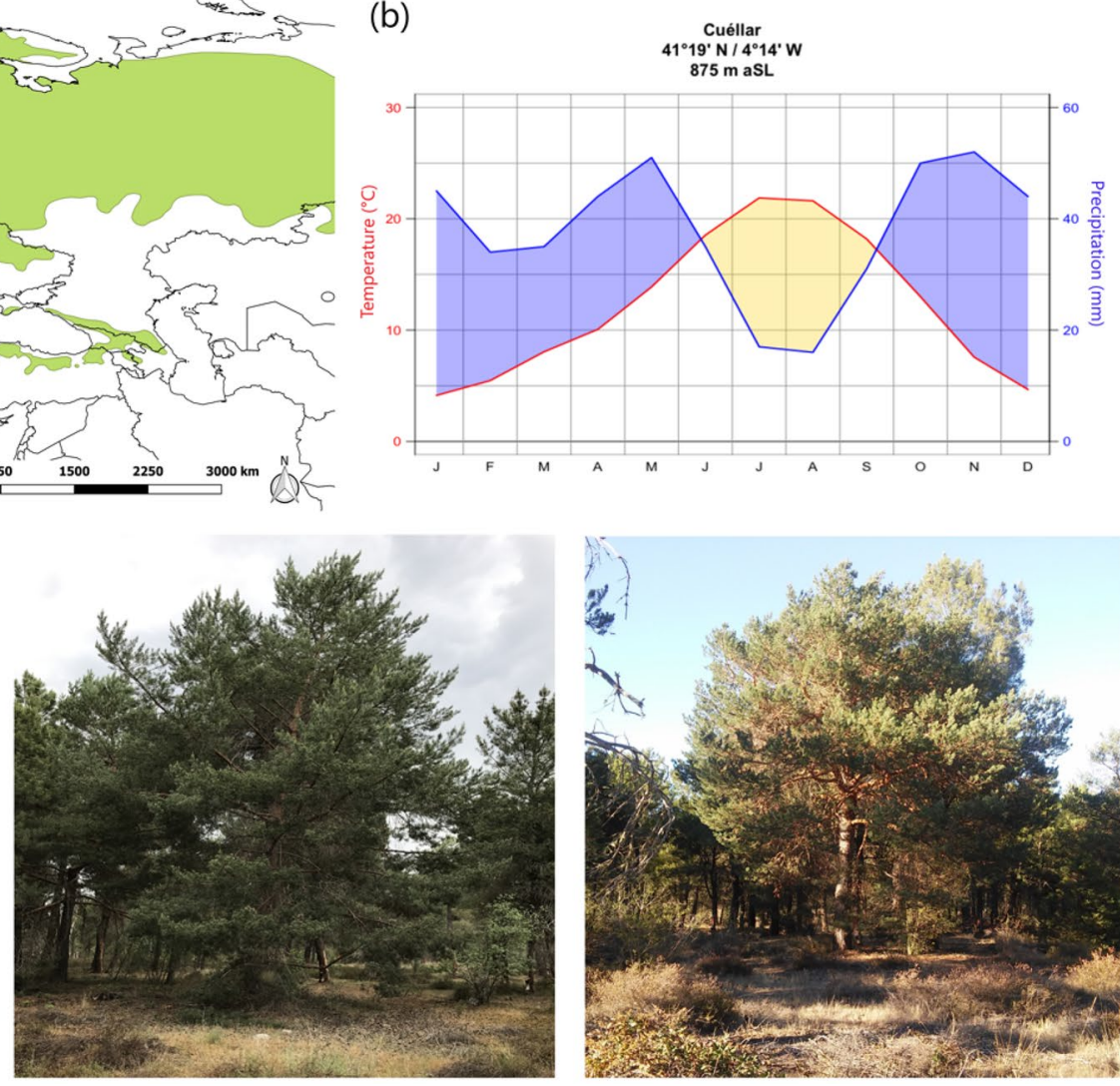

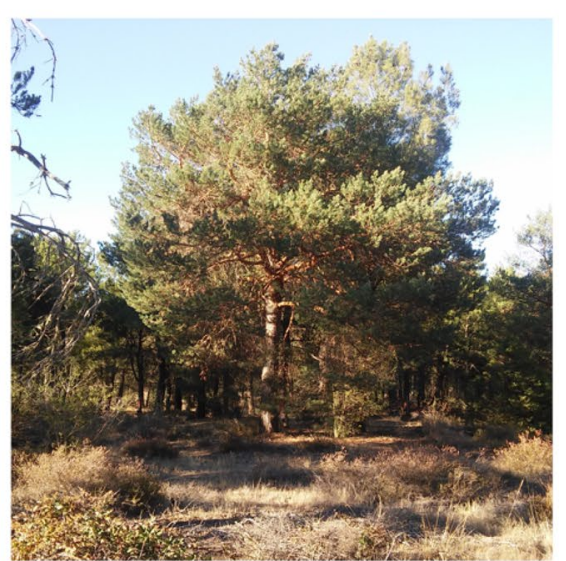

Fig. 1 a Geographical situation of the study area and distribution of Scots pine in Europe. b Climograph illustrating the climatic conditions at the study area. c Illustrative views of the Scots pine populations in three of the study sites. Species distributions are provided by EUFORGEN 
$\mathrm{AI}=\frac{\mathrm{P}}{\mathrm{PET}}$

where $\mathrm{P}$ is the annual total precipitation and PET is the potential evapotranspiration which was calculated following Thornthwaite (1948). Note that following this formulation, the aridity index increases with higher precipitation and lower PET (for more humid conditions), so it should be interpreted as water balance (Fig. 2a). Total annual precipitation and annual temperature were computed from September of the previous year to August of the present year so as to adapt climatic records to the most influential period for tree growth in this area (Madrigal-González et al. 2018). This climatic drought index is a good indicator of the soil water availability in the study area because of the high permeability of these sandy soils.

We focussed our study on two extreme drought events occurred in 2005 and 2012 ( $\mathrm{AI}=0.43$ and 0.45 , respectively), that had different characteristics. The 2005 drought was characterized by unusually low values of spring-summer precipitation that induced widespread growth decline and triggered forest dieback across many Iberian forests (Peñuelas et al. 2011; Carnicer et al. 2014; MadrigalGonzález et al. 2018). The 2012 drought was initiated by very warm and dry conditions during the previous winter and the early growing season, and it also caused canopy dieback and tree mortality (Camarero et al. 2015b).

\section{Dendrochronological methods and growth assessments}

Field sampling was done during 2016-2017. We established six circular sampling plots with a $25 \mathrm{~m}$ radius distributed across the Scots pine forest (see Supplementary Information, Appendix S1). As a prerequisite, a minimum number of 10 Scots pine target trees per sampling plot was needed. To quantify neighbourhood, we selected a fixed radius of $10 \mathrm{~m}$ from the target tree following previous studies applied in conifer forests (Stadt et al. 2007; He and Duncan 2000; Fraver et al. 2014), and Scots pine forests in particular (Pukkala and Kolström 1987; García-Abril et al. 2007; González de Andrés et al. 2017). To assure that the influence of neighbouring trees is properly caught, the core sampling area was defined within an inner $15 \mathrm{~m}$ radius, leaving a measured buffer area for the external part of the circle up to the $25 \mathrm{~m}$ radius in each plot. We measured target trees in the core sampling area (15 $\mathrm{m}$ radius) and neighbouring trees in each plot (25 m radius). Target trees were those whose growth was analysed as a response variable, whereas neighbouring trees were considered to have a competitive effect on target trees. As for the target trees we focussed on Scots pine; maritime pine and black pine were also included in the neighbourhood analysis, but not as target individuals. The centre of each sampling plot was mapped using a GPS with a resolution of $\pm 4 \mathrm{~m}$. Within each plot, the distance $(d)$ and the azimuth $(a)$ from the plot centre to each tree were measured with a rangefinder device $( \pm 1 \mathrm{~m})$ and a protractor placed on a tripod following the clockwise direction. The spatial position ( $\mathrm{x}-\mathrm{y}$ coordinates) of every tree in the plot was calculated using the trigonometric functions: $x=\sin (a) * d$ and $y=\cos (a) * d$. Diameter at breast height (DBH) was measured for each tree in the $25 \mathrm{~m}$ plot using a girth tape. Tree bark thickness was also measured using a bark gauge. Then, two cores were sampled per target tree, perpendicular to the maximum slope and in opposite directions, at $1.3 \mathrm{~m}$ using a Pressler increment borer. In total, 88 trees were sampled for a total of 176 increment cores (see Table 1).

The cores were prepared following standard dendrochronological methods (Fritts 2001). Wood samples were airdried, glued on wooden supports and polished on a sanding machine until tree rings were clearly visible. Tree-ring widths were visually cross-dated following the marker year method and measured to the nearest $0.01 \mathrm{~mm}$ using a binocular microscope and a LINTAB measuring device (Rinntech, Heidelberg, Germany) linked to a computer. Cross-dating of tree-ring sequences was checked using the programme COFECHA (Holmes 1983) (see Supporting Information, Appendix S2). To estimate tree age at $1.3 \mathrm{~m}$, pith-offset estimates were calculated by fitting a geometric pith locator to the innermost measured rings (Applequist 1958). For the oldest trees, tree age at $1.3 \mathrm{~m}$ was estimated by counting the
Table 1 Characteristics of the Scots pine trees sampled (values are means $\pm \mathrm{SD}$ ) in the six study plots. DBH is the diameter at breast height (measured at $1.3 \mathrm{~m})$

\begin{tabular}{llllll}
\hline Plot & $\begin{array}{l}\text { No. trees (no. } \\
\text { cores) }\end{array}$ & $\begin{array}{l}\text { Basal area target trees } \\
\left(\mathrm{m}^{2} \mathrm{ha}^{-1}\right)\end{array}$ & $\begin{array}{l}\text { Basal area all trees } \\
\left(\mathrm{m}^{2} \mathrm{ha}^{-1}\right)\end{array}$ & DBH $(\mathrm{cm})$ & $\begin{array}{l}\text { Age at } \\
1.3 \mathrm{~m} \\
\text { (years) }\end{array}$ \\
\hline 1 & $31(61)$ & 14.82 & 31.37 & $33.0 \pm 5.0$ & $49 \pm 6$ \\
2 & $10(21)$ & 10.27 & 34.42 & $45.0 \pm 14.4$ & $56 \pm 9$ \\
3 & $10(20)$ & 6.07 & 50.05 & $38.7 \pm 4.8$ & $42 \pm 4$ \\
4 & $12(25)$ & 8.11 & 32.61 & $40.0 \pm 9.8$ & $47 \pm 7$ \\
5 & $13(24)$ & 9.99 & 40.33 & $43.6 \pm 4.6$ & $58 \pm 7$ \\
6 & $12(24)$ & 5.86 & 17.68 & $33.7 \pm 9.6$ & $32 \pm 7$ \\
\hline
\end{tabular}


rings in the core of living trees and adding the estimated length of core missing up to the predicted pith.

To quantify growth, tree-ring width series were converted into basal area increment (BAI) which provides a biologically meaningful variable as BAI shows trends which are typically linear and less dependent on tree age and size than tree-ring width (Biondi and Qeadan 2008). We used the following formula and assumed a circular shape of the stems:

$\mathrm{BAI}=\pi\left(r_{t}^{2}-r_{t-1}^{2}\right)$

where $r_{t}$ ad $r_{t-1}$ are the stem radial increments at the end and the beginning of a given annual ring increment corresponding to rings formed in $t$ and $t-1$ years, respectively.

\section{Effects of competition on tree growth}

We reconstructed diameters at $1.3 \mathrm{~m}$ for all trees to calculate values prior to the sampling date. We focussed our analysis on the period 1980-2015 to reduce uncertainties of the DBH reconstruction and competition calculation back in time. Annual diameter increments for target trees were estimated by multiplying the ring width measurements from the cores by two. Diameter increments of cored trees were fitted against time using Generalized Additive Mixed models (GAMMs, Wood 2017). Based on the adjusted model and the DBH measurements taken in 2015, annual diameter increments of non-cored trees were reconstructed back to 1980 . Finally, we added bark thickness and calculated the diameter for each tree and each year during the period 1980-2015. The variance explained by the GAMMs ranged between 0.216 and 0.644 .

We described the effects of competition in terms of growth per year $(t)$ using a simple density and distancedependent function predicting growth increases with target tree size and growth declines towards zero with rising neighbourhood size in relation to their proximity to the target tree:

Growth $_{t}=\frac{\mathrm{BA}_{i}^{\alpha}}{\sum_{j=1}^{n}\left(\frac{\mathrm{BA}_{j}}{d_{i j}}\right)^{\beta}}$

where the individual component of competition (numerator) was the basal area of the target tree $i$ and the neighbourhood component of competition (denominator) was the basal area of the neighbour tree $j$ divided by the distance between $i$ and $j$ and summed over all $j$ neighbouring trees within a radius of $10 \mathrm{~m}$ from the target tree $i$, as the maximum search distance evaluated.

\section{Statistical analysis}

Firstly, we estimated the parameters $\alpha$ and $\beta$ for each year using maximum likelihood methods (Canham et al. 2004).
This non-linear mixed effect model (Eq. 3) assumes that the ability of trees to capture light and nutrients depends on the total basal area of the target and neighbouring trees. The non-linear model was fitted using the stochastic approximation expectation maximisation (SAEM) algorithm (Comets et al. 2017), which estimates the population parameters per each year and includes a random intercept term associated with non-independent sampling (i.e., plot identity). The target tree size $(\alpha)$ and the neighbourhood $(\beta)$ components of competition were estimated over the study period 1980-2015. Neighbourhood was established with a fixed radius of $10 \mathrm{~m}$ from each target tree, and parameters estimation was repeated with a smaller fixed radius of $6 \mathrm{~m}$ to ensure support for our conclusions (see Appendix S3).

Secondly, we fitted linear mixed-effects models to assess the effect of climate on the individual and neighbourhood components of competition (i.e., parameters $\alpha$ and $\beta$ ) for the period 1980-2015. To control for the long-term linear trend associated with tree size development in the neighbourhood, the stand basal area (SBA) was included in the models. The general structure of the models can be summarized as:

$Y_{t}=X a_{t}+Z b+\varepsilon_{t}$

where $Y_{t}$ represents the $\alpha$ and $\beta$ components from the nonlinear model per year $t, a$ is the vector of fixed effects (i.e., $\mathrm{AI}$ and SBA for each year), $b$ is the vector of random effects, (i.e., plot identity), $X$ and $Z$ are regression matrices of fixed and random effects, respectively, and $\varepsilon_{t}$ is the within-group error vector. A first-order autocorrelation structure was included in the models. The predictor variables (AI and SBA) were standardized (i.e. the mean was subtracted from the variable, and the resulting value was divided by the variable's standard deviation). We performed a moving window analysis with a 15-year window to explore when and how the effect of climate had more importance on competition dynamics (Ives et al. 2010). A sensitivity analysis was conducted to test the importance of the length of the moving window (10 to 15 and 20 years) and the results are included in Appendix S4. Residuals of the models were checked for normality and homoscedasticity. Fixed effects selection was based on Akaike Information Criterion corrected for small sample size (AICc). For each time window, we selected the model with the lowest AICc as being the most parsimonious model (Burnham and Anderson 2002). We considered the models with substantial support to be those in which the difference in AICc between the full model and the model without AI was negative and smaller than -4 .

The abovementioned analyses were performed using the R statistical software version 3.4.3 (R Core Team 2018). Tree-ring data were processed via the $d p l R$ package (Bunn et al. 2018). Generalized additive mixed models were computed using the $m g c v$ package (Wood 2017). Competition 
effects were modelled with the saemix package in R (Comets et al. 2017). Linear mixed-effects models were conducted using nlme (Pinheiro et al. 2018).

\section{Results}

\section{Growth patterns}

Tree growth showed similar patterns across all plots (Fig. 2b), with BAI decreasing strongly during the dry years 1986, 1992, 2005 and 2012. Scots pine showed an increase in BAI until the early 1990s when BAI stabilized at values of $10-30 \mathrm{~cm}^{2}$ year $^{-1}$ (Fig. 2b). At plot 6 , Scots pine individuals were the youngest such that BAI stabilized only in the late 1990s. The lowest values of BAI were found at plot $1\left(8.79 \pm 6.31 \mathrm{~cm}^{2}\right.$ year $\left.^{-1}\right)$, while the highest values corresponded to plot $3\left(21.23 \pm 9.57 \mathrm{~cm}^{2}\right.$ year $\left.{ }^{-1}\right)$. Mean DBH of sampled trees ranged from 33.0 to $45.0 \mathrm{~cm}$, and age at $1.3 \mathrm{~m}$ varied from 32 to 58 years (see Table 1), confirming the stand establishment of the Scots pine population after the last clear-cutting in the 1960s.

Stand basal area reached the highest values at plot 3 $\left(50.05 \mathrm{~m}^{2} \mathrm{ha}^{-1}\right)$, where stand density was also highest (140 trees ha ${ }^{-1}$; see Appendix S1). The lowest values found at plot $6\left(17.68 \mathrm{~m}^{2} \mathrm{ha}^{-1}\right)$ corresponded to the youngest individuals (Fig. 2c). Growth of the Scots pine trees was positively correlated with target tree size (Appendix S5a), and negatively correlated with total basal area of all neighbouring trees located within the area around a target stem (Appendix S5b).
Fig. 2 a Climatic patterns in the study area illustrated by the aridity index (AI, higher values indicate higher water balance) over 1980-2015. b Basal area increment (BAI, $\mathrm{cm}^{2}$ year $^{-1}$ ) of Scots pine target trees and $\mathbf{c}$ stand basal area (SBA, m $\mathrm{ha}^{-1}$ ) of all trees in the six study plots for the same period
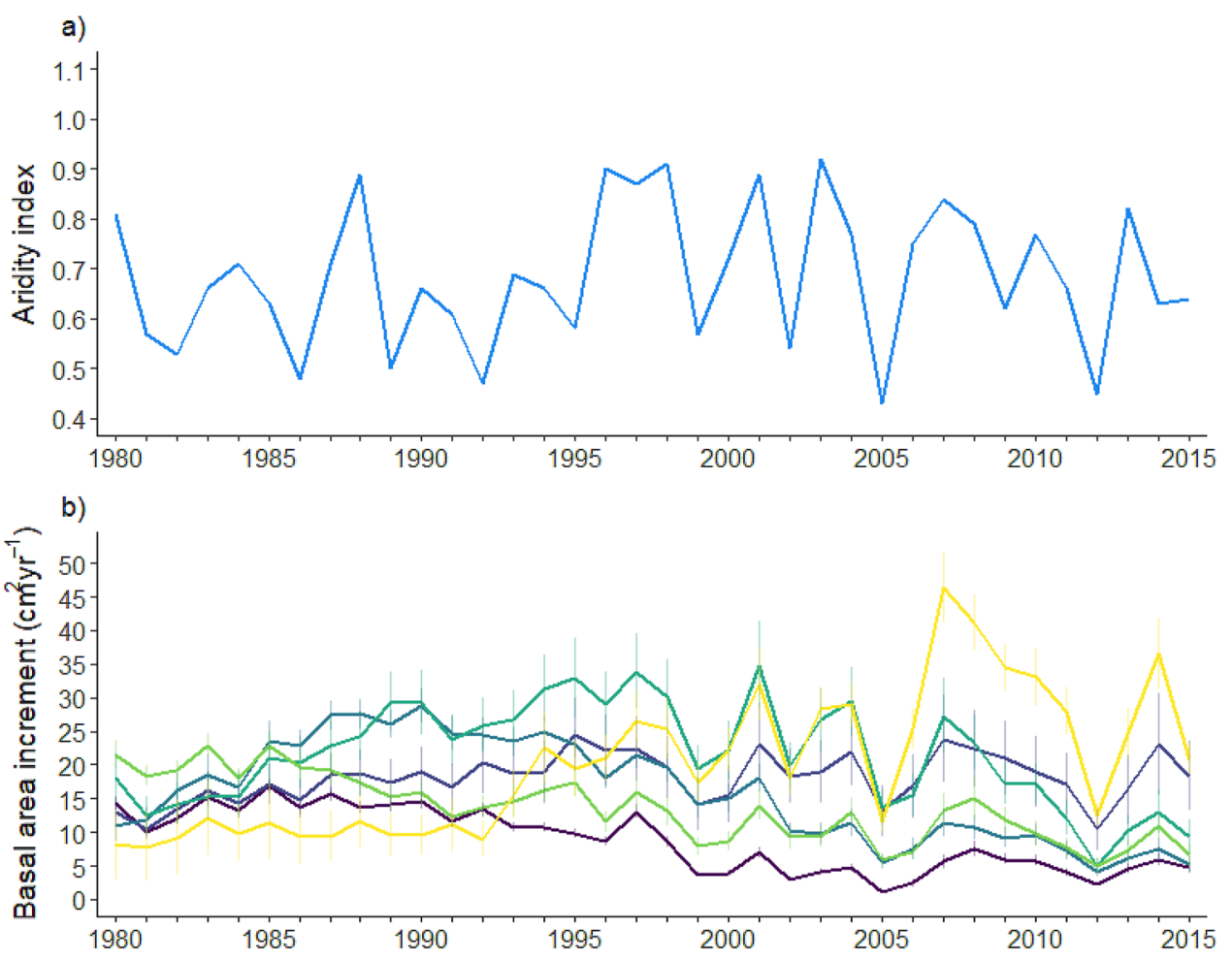

c)

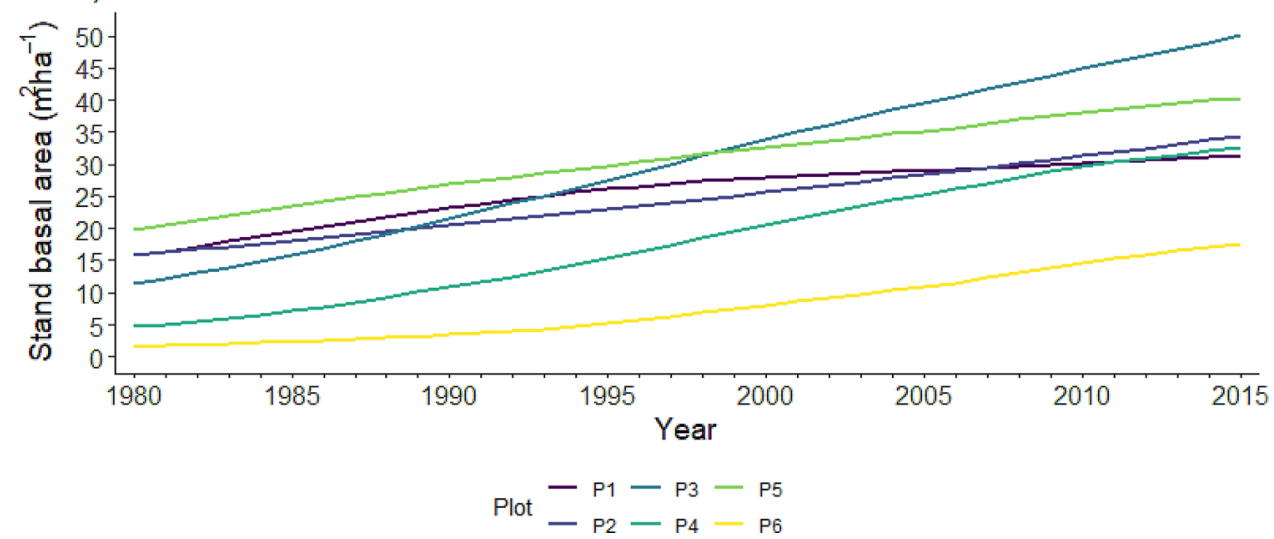




\section{Competition effects on tree growth}

The individual component $(\alpha)$ was significantly positive all over the study period 1980-2015, with higher values indicating stronger opposing effects of basal area of target trees on neighbours' negative influence (Fig. 3a). The $\alpha$ estimated for Scots pine during the study period varied from 0.57 to 0.78 . The parameter $\alpha$ showed an increasing tendency up to 1995 , when the parameter stabilized, before it tended to decrease by the end of the period. From 1980 to 1995, the lowest $\alpha$ values were observed in 1981 and 1988, whereas after 1995, the lowest $\alpha$ values were reached in 2009, 2010, 2012 and 2015 and the highest in 2001.

The parameter controlling the effects of neighbourhood basal area on target tree growth $(\beta)$ showed a consistent positive trend for the study period $1980-2015$, with higher values indicating a stronger negative influence of the neighbourhood on tree growth (Fig. 3b). The $\beta$ estimated for Scots pine varied from 0.09 to 0.38 . However, $\beta$ was only slightly significant until 1990, and since then the neighbourhood competition showed a significant effect over the period. The highest significant $\beta$ values were found in 2002, 2005 and 2012 whereas the lowest $\beta$ values were found in 1988, 1997 and 2009.

Comparison of parameters $\alpha$ and $\beta$ as estimated by considering the neighbourhood with a fixed radius of $10 \mathrm{~m}$ vs. $6 \mathrm{~m}$ are shown in Appendix S3. Pearson correlations yielded values of 0.90 for the target component $(\alpha)$ and 0.96 for the neighbourhood component $(\beta)$ of competition for both fixed radius analyses. Along the study period, parameters did not show differences between the neighbourhood radius considered as shown by the overlapping errors, with the exception
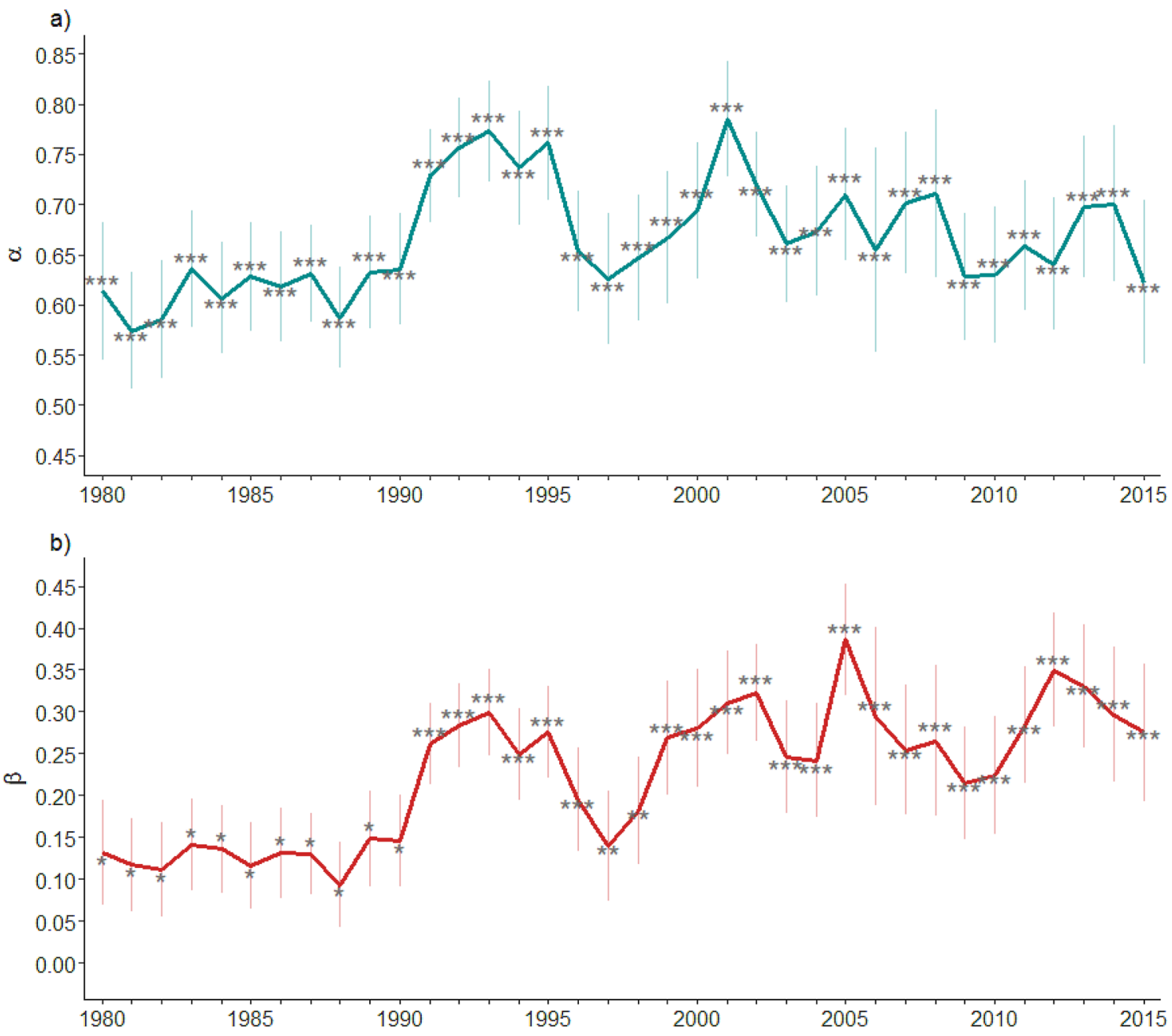

Fig. 3 Parameter estimations for both $\mathbf{a}$ the target size $(\alpha)$ and $\mathbf{b}$ the neighbourhood $(\beta)$ components of competition over the study period 1980-2015. Neighbourhood is established with a fixed radius of $10 \mathrm{~m}$ from each target tree. Line charts are the means of the parameters and error bars are the standard errors (SE) of the parameter estimates. Parameters significance is annotated for each year as follows: ns $(p>0.05), *(p<0.05), * *(p<0.01), * * *(p<0.001)$ 
of years 1991-1993, where differences were consistent in both parameters $\alpha$ and $\beta$.

\section{Influence of climate on competition components}

The moving window analysis identified the time periods for which the aridity index had an influence on competition dynamics (Table 2). The AI affected the individual component of competition $(\alpha)$ in the 1980s and 1990s (1983-1998), and to a lesser extent to the early 2000s. During this period of time AI had a negative effect on the individual component. The neighbourhood component $(\beta)$ was mainly affected by AI from 1991 to 2015. Particularly, the effect was stronger when a dry year was included in the time window, specifically 1992, 1994-1995, 2005 and 2012. Along the entire period, the neighbourhood component of competition decreased under wetter and cooler conditions

Table 2 Model comparison for both target tree size and neighbourhood components of competition ( $\alpha$ and $\beta$ ) based on Akaike Information Criterion corrected for small sample size (AICc) for moving window analysis of 15 years

\begin{tabular}{|c|c|c|c|c|}
\hline \multirow[t]{2}{*}{ Time window } & \multicolumn{2}{|c|}{ Individual component $(\alpha)$} & \multicolumn{2}{|c|}{$\begin{array}{l}\text { Neighbourhood com- } \\
\text { ponent }(\beta)\end{array}$} \\
\hline & $\mathrm{AI}$ & $\Delta \mathrm{AICc}$ & $\mathrm{AI}$ & $\Delta \mathrm{AICc}$ \\
\hline 1980-1994 & 0.005 & 9.928 & -0.002 & 11.685 \\
\hline 1981-1995 & -0.001 & 11.943 & -0.004 & 10.149 \\
\hline 1982-1996 & -0.014 & 2.487 & -0.014 & -1.332 \\
\hline 1983-1997 & -0.017 & -5.625 & -0.015 & -6.888 \\
\hline 1984-1998 & -0.016 & -1.735 & -0.014 & -0.566 \\
\hline 1985-1999 & -0.011 & 3.647 & -0.015 & -3.998 \\
\hline 1986-2000 & -0.010 & 5.610 & -0.013 & -0.001 \\
\hline 1987-2001 & -0.009 & 7.290 & -0.013 & -1.244 \\
\hline 1988-2002 & -0.005 & 10.217 & -0.012 & -2.050 \\
\hline 1989-2003 & 0.000 & 11.473 & -0.011 & 1.696 \\
\hline 1990-2004 & -0.003 & 10.959 & -0.010 & 2.276 \\
\hline 1991-2005 & -0.013 & 5.333 & -0.038 & -32.068 \\
\hline 1992-2006 & -0.017 & 0.828 & $-\mathbf{0 . 0 3 9}$ & -36.425 \\
\hline 1993-2007 & -0.016 & 3.075 & -0.041 & -37.243 \\
\hline 1994-2008 & -0.014 & 4.662 & -0.042 & -38.151 \\
\hline 1995-2009 & -0.011 & 7.459 & -0.035 & -20.105 \\
\hline 1996-2010 & -0.002 & 10.767 & -0.031 & -16.142 \\
\hline $1997-2011$ & -0.001 & 10.925 & -0.031 & -15.620 \\
\hline 1998-2012 & 0.002 & 10.981 & -0.030 & -16.929 \\
\hline 1999-2013 & 0.005 & 10.151 & -0.026 & -9.649 \\
\hline 2000-2014 & 0.002 & 10.884 & $-\mathbf{0 . 0 3 0}$ & -8.793 \\
\hline 2001-2015 & 0.001 & 10.713 & -0.034 & -7.227 \\
\hline
\end{tabular}

The $\triangle \mathrm{AICc}$ was estimated as the difference between the full model with stand basal area (SBA) and aridity index (AI) as main effects and the model without AI. Models with significant effects are determined by more negative values of $\triangle \mathrm{AICc}$ and are given in bold (negative effect of AI on $\beta$ ). Interestingly, a sensitivity analyses conducted on these estimates supported the idea that the influence of aridity on neighbourhood effects was mostly determined in time-windows with marked fluctuations of the AI. Correlations between AI variability (SD) and $\triangle \mathrm{AICc}$ resulted in $r=-0.62(p<0.001)$.

\section{Discussion}

In this study, we evaluated individual and neighbourhood components of competition over time, as well as their influence on tree growth according to climate conditions, with an emphasis on drought effects. Our results indicate that competitive effects change over time, and support an intensification of competitive influences on tree growth in dry years and, in particular, during the 2005 and 2012 dry spells. The contribution associated with mean target tree size showed an increasing trend during early successional stages as a consequence of the population increase, and tended to decrease towards the end of the period. The competition related to neighbourhood size revealed a progressive linear increase across time, with higher values occurring in dry years. We also identified the time period during which the aridity index mostly influenced competition dynamics. In particular, we found a significant negative effect on neighbourhood competition, which illustrate the modulating role of climatic variability on stand dynamics over time. Nonetheless, the influence of climate controlling the neighbourhood component of competition was evident in periods with high fluctuations in the AI, which denotes a major role of climate extremes driving tree-to-tree competition.

During the 1980s, the individual component of competition was more important than the neighbourhood component as trees established in the stand and occupied the available space. This finding is consistent with general patterns described in literature where tree growth of young individuals was found to increase rapidly because of growing space of individual trees (Long et al. 2004; Benedict and Frelich 2008). At this early stage of stand development, competing understory vegetation can also exert a control on tree growth, as shown by Zhang et al. (2013) for a ponderosa pine forest plantation in Northern California. A decreasing relative effect of the individual component of competition and an increasing neighbourhood competition by the end of the period also suggests that competitive interactions intensify with increasing tree size. The continuous tree size development modulates growth (Stephenson et al. 2014), stand productivity (Coomes et al. 2014), and within-population interactions (Le Roux et al. 2013). Competition effects have been seen to increase faster in denser stands (GarcíaAbril et al. 2007; Sohn et al. 2016; Del Río et al. 2017), and intensified due to lower water availability (Marqués et al. 
2018). Stand development implies an increasing stand basal area and stand density leading to forest encroachment, and a reduction on space availability that may lead to an intensification in tree-to-tree interactions (Aldea et al. 2017).

In fact, we found that the neighbourhood component of competition exerted an increasing negative influence on radial growth of Scots pine trees (Jäghagen and Albrektson 1996), with significant effects since 1991. Strong impacts of neighbourhood competition on Scots pine growth may be explained by the high susceptibility of this species to competition for light (Jucker et al. 2014). The strong negative relationship between stand density and mean tree size in a population over time refers to the so-called self-thinning (Yoda et al. 1963). It has been reported that small trees are more affected by light competition than taller trees (Weiner 1990; Coomes and Allen 2007). Noteworthy, shade and drought have been shown to have interactive effects on plant performance (Holmgren et al. 1997; Sack 2004). Under drier conditions, taller trees may offer partial shade to smaller trees, reducing evapotranspiration and thus maintaining soil moisture availability (Joffre and Rambal 1993). Larger pine stems, by contrast, may also experience increasing vulnerability to drought (Hember et al. 2017), reflecting rising hydraulic and respiration costs with increasing tree height (Ryan et al. 2006). In addition, taller trees are subject to greater wind stress, resulting in reduced leaf area (Oliver and Larson 1996). Increased aridity may intensify neighbourhood competition over the target tree size effect, such that competition may become more symmetric, i.e., larger individuals may not compensate for the negative effect of neighbourhood competition effects (Stoll et al. 1994). Similar results were suggested by Masaki et al. (2006), who showed that the degree of size-asymmetrical competition decreases with stand age. Pretzsch and Dieler (2010) also predicted that increased stress limits the monopolization of resources from large trees, and thus reduces self-thinning of smaller trees. Pothier (2017) reached similar conclusions using a different analytical approach, suggesting these results are supported by a growing body of evidence. In this study, from 2005 onwards, both components of competition were uncoupled through time. This effect was particularly pronounced during the extreme drought of 2012, in which the individual component of competition decreased whereas the neighbourhood component increased. This finding is in line with results from other drought-limited forests, where competition has also been seen to become inverse size-asymmetric, thereby impacting larger trees disproportionately (Biondi 1996). In the future, self-thinning processes could even be anticipated and occur at early stages of population development if droughts were to become more frequent and/ or severe, with a direct rise in mortality rates (Ruiz-Benito et al. 2013).
In principle, our findings are in line with general effects of changes in light and space availability on forest dynamics (Oliver and Larson 1996; Callaway and Walker 1997). In Mediterranean climates, however, water availability can modify species responses to light competition (Zavala and Bravo de la Parra 2005; Vilà-Cabrera et al. 2014). Our results suggest that the aridity index had a negative effect on the neighbourhood component of competition from the middle towards the end of the study period. These effects of water balance on the neighbourhood component of competition were consistent with the limiting role that water plays in the Mediterranean ecosystems. Also, sensitivity to competition increased with rising temperatures for Mediterranean forests, which could be linked to a higher transpiration demand and an increase in water scarcity. These results agree with the prediction that climate warming would increase competition for water in Mediterranean forests (Cotillas et al. 2009; Linares et al. 2010). Surprisingly, the aridity index showed a relatively small, but negative effect on the individual component of competition when analysing the time window 1983-1997, probably due to the early stage of the population at that time.

Our findings also agree with previous studies stating that competition may negatively interact with those climate conditions affecting tree growth (Piutti and Cescatti 1997; Fernández-de-Uña et al. 2015; Bottero et al. 2017; Andrews et al. 2020). Scots pine was found to be subject to higher competition in dry years by Weber et al. (2008) when studying competitive dynamics of pines and oaks over time in Valais (Switzerland). Other studies also found tree growth and competition effects to be highly dependent on local climatic conditions (Gómez-Aparicio et al. 2011; SánchezSalguero et al. 2015; Madrigal-González et al. 2016). In that sense, drought constraints on growth are particularly important in the southernmost dry limits of the tree species distribution (Hampe and Petit 2005; Sánchez-Salguero et al. 2016). Strong competition may exacerbate water shortage and therefore influence vulnerability of forests to recurrent drought events (McDowell et al. 2008). Climate conditions controlling the neighbourhood component of competition were more evident in periods with very high fluctuations in the aridity index, which denotes a major influence of climate variability affecting competition as compared to regular climatic fluctuations.

Previous field studies on competition in forest communities were conducted mainly by studying either mature trees at a given time (Ledo et al. 2014; Buechling et al. 2017) or juvenile trees over a short time period (Davis et al. 1999; Caldeira et al. 2014; Benavides et al. 2016). Our study shows evidence of tree-to-tree competition effects in a dry-edge population and its temporal variability. Although our findings are based on radial growth measurements and partial tree size reconstructions along a temporal gradient 
in a natural environmental rather than on experiments, the observed growth patterns indeed allow us to suggest potential mechanisms associated with the two components of competition in the studied system. We found that competitive interactions in the context of stand development were dynamic, as was shown by the oscillations in the components of competition trends. The resulting neighbourhood component of competition was influenced significantly by higher climatic fluctuations. Our results therefore constitute relevant new information, which furthers our understanding of how tree competition interactions and stand structure will influence stand dynamics under more severe drought episodes in a context of climate change. Future research should complement our findings with other proxies of tree functioning related to water-use efficiency, such as carbon isotope discrimination in tree rings (e.g. González de Andrés et al. 2017).

\section{Conclusions}

Our study confirmed the expectation that competition effects vary over time and that their influence on tree growth is intensified during drought events in marginal Scots pine populations. We found a significant, positive effect of the individual component of competition which decreased by the end of the period, and a significant negative effect of neighbourhood competition after the population establishment which increased progressively with time. We also found significant evidence that climate modulated the competition effects during stand development, with the aridity index negatively affecting neighbouring tree size. Our study is one of the first attempts to examine the variation of competition effects over time considering climate variability in a dry-edge Scots pine population. Our results therefore provide key insights into inter-annual variability in competition effects depending on population dynamics and climatic conditions, and also highlight the complexity of competitive interactions in drought-prone forest ecosystems. The findings presented here are also relevant to better understand interactions among biotic and climatic mechanisms driving tree populations subjected to seasonal droughts, with the goal of preserving their functioning under future climatic changes.

\section{Author contribution statement}

JMG conceived the study and designed the methodology; JMG, CSG and LM collected the data; JMG, LM and JJC conducted the lab work; LM conducted the statistical analysis and led the writing of the manuscript; JJC and MAZ devised conceptual ideas and provided project support;
JABC and MS added substantial edits to the manuscript. All authors contributed critically to the drafts and gave final approval for publication.

Supplementary Information The online version contains supplementary material available at https://doi.org/10.1007/s00468-021-02109-8.

Acknowledgments We thank Daniel Gómez and Patricia GonzálezDíaz for their support during field work. L. Marqués acknowledges funding from University of Alcalá for a mobility grant at the Institute for Environmental Sciences (University of Geneva), and thanks all members of the C-CIA group for their helpful advices. L. Marqués was supported by a FPI grant from the University of Alcalá. We acknowledge funding provided by projects VULPINECLIM (Spanish Ministry of Economy and Competitiveness, MINECO, Spain; CGL2013-44553-R) and FUNDIVER (MINECO, Spain; CGL2015-69186C2-1-R and CGL2015-69186-C2-2-R projects).

Funding Open access funding provided by Swiss Federal Institute of Technology Zurich.

Open Access This article is licensed under a Creative Commons Attribution 4.0 International License, which permits use, sharing, adaptation, distribution and reproduction in any medium or format, as long as you give appropriate credit to the original author(s) and the source, provide a link to the Creative Commons licence, and indicate if changes were made. The images or other third party material in this article are included in the article's Creative Commons licence, unless indicated otherwise in a credit line to the material. If material is not included in the article's Creative Commons licence and your intended use is not permitted by statutory regulation or exceeds the permitted use, you will need to obtain permission directly from the copyright holder. To view a copy of this licence, visit http://creativecommons.org/licenses/by/4.0/.

\section{References}

Aakala T, Berninger F, Starr M (2018) The roles of competition and climate in tree growth variation in northern boreal old-growth forests. J Veg Sci 29(6):1040-1051

Aldea J, Bravo F, Bravo-Oviedo A et al (2017) Thinning enhances the species-specific radial increment response to drought in Mediterranean pine-oak stands. Agric For Meteorol 237-238:371-383

Andrews CM, D'Amato AW, Fraver S et al (2020) Low stand density moderates growth declines during hot-droughts in semi-arid forests. J Appl Ecol 205:344

Applequist MB (1958) A simple pith locator for use with off- center increment cores. J For 56:141

Barbero M, Loisel Q et al (1998) Pines of the Mediterranean basin. Ecology and biogeography of Pinus. Cambridge University Press, Cambridge, pp 153-170

Benavides R, Escudero A, Coll L et al (2016) Recruitment patterns of four tree species along elevation gradients in Mediterranean mountains: not only climate matters. For Ecol Manage 360:287-296

Benedict MA, Frelich LE (2008) Site factors affecting black ash ring growth in northern Minnesota. For Ecol Manage 255:3489-3493

Berntson AGM, Wayne PM (2000) Characterizing the size dependence of resource acquisition within crowded plant populations. Ecology 81:1072-1085

Biging GS, Dobbertin M (1995) Evaluation of competition indices in individual tree growth models. For Sci 41(2):360-377 
Biondi F (1996) Decadal-scale dynamics at the Gus Pearson Natural Areas: evidence for inverse (a)symmetric competition? Can J For Res 26:1397-1406

Biondi F, Qeadan F (2008) A theory-driven approach to tree-ring standardization Defining the biological trend expected basal area increment. Tree-ring Res 64:81-96

Bottero A, D'Amato AW, Palik BJ et al (2017) Density-dependent vulnerability of forest ecosystems to drought. J Appl Ecol 54:1605-1614

Brooker RW, Callaghan TV (1998) The Balance between positive and negative plant interactions and its relationship to environmental gradients: a model. Oikos 81:196-207

Buechling A, Martin PH, Canham CD (2017) Climate and competition effects on tree growth in Rocky Mountain forests. J Ecol 105:1636-1647

Bunn A, Korpela M, Biondi F et al (2018) dplR: dendrochronology program library in R. R Packag version 1(6):9

Burnham KP, Anderson DR (2002) Model Selection and multimodel inference: a practical information-theoretic approach, 2nd edn. Springer

Burton PJ (1993) Some limitations inherent to static indices of plant competition. Can J For Res 23:2141-2152

Caldeira MC, Ibáñez I, Nogueira C et al (2014) Direct and indirect effects of tree canopy facilitation in the recruitment of Mediterranean oaks. J Appl Ecol 51:349-358

Callaway RM, Walker LR (1997) Competition and facilitation: a synthetic approach to interactions in plant communities. Ecology 78:1958-1965

Camarero J, Gazol A, Sancho-Benages S, Sangüesa-Barreda G (2015a) Know your limits? Climate extremes impact the range of Scots pine in unexpected places. Ann Bot 116:917-927

Camarero JJ, Gazol A, Sangüesa-Barreda G et al (2015b) To die or not to die: early warnings of tree dieback in response to a severe drought. J Ecol 103:44-57

Canham CD, LePage PT, Coates KD (2004) A neighborhood analysis of canopy tree competition: effects of shading versus crowding. Can J For Res 34:778-787

Canham CD, Papaik MJ, Uriarte M et al (2006) Neighborhood analyses of canopy tree competition along environmental gradients in New England forests. Ecol Appl 16:540-554

Carnicer J, Coll M, Pons X et al (2014) Large-scale recruitment limitation in Mediterranean pines: the role of Quercus ilex and forest successional advance as key regional drivers. Glob Ecol Biogeogr 23:371-384

Comets E, Lavenu A, Lavielle M (2017) Parameter estimation in nonlinear mixed effect models using saemix, an R implementation of the SAEM algorithm. J Stat Softw 80:1-41

Coomes DA, Allen RB (2007) Effects of size, competition and altitude on tree growth. J Ecol 95:1084-1097

Coomes DA, Flores O, Holdaway R et al (2014) Wood production response to climate change will depend critically on forest composition and structure. Glob Chang Biol 20:3632-3645

Cotillas M, Sabaté S, Gracia C, Espelta JM (2009) Growth response of mixed mediterranean oak coppices to rainfall reduction. Could selective thinning have any influence on it? For Ecol Manage 258:1677-1683

Das A, Battles J, van Mantgem PJ, Stephenson NL (2008) Spatial elements of mortality risk in old-growth forests. Ecology 89:1744-1756

Davis MA, Wrage KJ, Reich PB et al (1999) Survival, growth, and photosynthesis of tree seedlings competing with herbaceous vegetation along a multiple resource gradient. Plant Ecol 145:341-350

De Luis M, Raventós J, Cortina J, Moro MJ, Bellot J (1998) Assessing components of a competition index to predict growth in an evenaged Pinus nigra stand. New Forest 15:223-242
Del Río M, Bravo-Oviedo A, Pretzsch H et al (2017) A review of thinning effects on Scots pine stands: from growth and yield to new challenges under global change. For Syst 26:eR03S

Doblas-Miranda E, Alonso R, Arnan X et al (2017) A review of the combination among global change factors in forests, shrublands and pastures of the Mediterranean Region: Beyond drought effects. Glob Planet Change 148:42-54

Fernández-de-Uña L, Cañellas I, Gea-Izquierdo G (2015) Stand competition determines how different tree species will cope with a warming climate. PLoS ONE 10:1-18

Fraver S, D'Amato AW, Bradford JB, Jonsson BG, Jönsson M, Esseen PA (2014) Tree growth and competition in an old-growth Picea abies forest of boreal Sweden: influence of tree spatial patterning. J Veg Sci 25:374-385

Fritts HC (2001) Tree rings and climate. Blackburn Press, Caldwell

García-Abril A, Martin-Fernández S, Grande MA, Manzanera JA (2007) Stand structure, competition and growth of Scots pine (Pinus sylvestris L.) in a Mediterranean mountainous environment. Ann For Sci 64:825-830

Gómez-Aparicio L, García-Valdés R, Ruíz-Benito P, Zavala MA (2011) Disentangling the relative importance of climate, size and competition on tree growth in Iberian forests: Implications for forest management under global change. Glob Chang Biol 17:2400-2414

Gómez-Sanz V, Garcia-Viñas JI (2011) Soil moisture spatio-temporal behavior of Pinus pinaster stands on sandy flatlands of central Spain. For Syst 20(293):302

González de Andrés E, Camarero JJ, Blanco JA et al (2017) Tree-totree competition in mixed European beech-Scots pine forests has different impacts on growth and water-use efficiency depending on site conditions. J Ecol 106:59-75

Hampe A, Petit RJ (2005) Conserving biodiversity under climate change: the rear edge matters. Ecol Lett 8:461-467

He F, Duncan RP (2000) Density-dependent effects on tree survival in and old-growth Douglas-fir forest. J Ecol 88:676-688

Hember RA, Kurz WA, Coops NC (2017) Relationships between individual-tree mortality and water-balance variables indicate positive trends in water stress-induced tree mortality across North America. Glob Chang Biol 23:1691-1710

Holmes RL (1983) Computer-assisted quality control in tree-ring dating and measurement. Tree-Ring Bull 43:69-78

Holmgren M, Scheffer M, Huston M (1997) The interplay of facilitation and competition on plant communities. Ecology 78:1966-1975

Ives AR, Abbott KC, Ziebarth NL (2010) Analysis of ecological time series with ARMA(p, q) models. Ecology 91:858-871

Jäghagen K, Albrektson A (1996) Induced competition among Scots pine seedlings and its effect on future timber quality. New For 12:163-174

Joffre R, Rambal S (1993) How tree cover influences the water balance of Mediterranean rangelands. Ecology 74:570-582

Jucker T, Bouriaud O, Avacaritei D et al (2014) Competition for light and water play contrasting roles in driving diversity-productivity relationships in Iberian forests. J Ecol 102:1202-1213

Jump AS, Ruiz-Benito P, Greenwood S et al (2017) Structural overshoot of tree growth with climate variability and the global spectrum of drought-induced forest dieback. Glob Chang Biol 23:3742-3757

Keddy P (2001) Competition. Springer

Kunstler G, Albert CH, Courbaud B et al (2011) Effects of competition on tree radial-growth vary in importance but not in intensity along climatic gradients. J Ecol 99:300-312

Le Roux PC, Shaw JD, Chown SL (2013) Ontogenetic shifts in plant interactions vary with environmental severity and affect population structure. New Phytol 200:241-250

Ledo A, Cañellas I, Barbeito I et al (2014) Species coexistence in a mixed Mediterranean pine forest: Spatio-temporal variability in 
trade-offs between facilitation and competition. For Ecol Manage 322:89-97

Linares JC, Camarero JJ, Carreira JA (2010) Competition modulates the adaptation capacity of forests to climatic stress: Insights from recent growth decline and death in relict stands of the Mediterranean fir Abies pinsapo. J Ecol 98:592-603

Long JN, Dean TJ, Roberts SD (2004) Linkages between silviculture and ecology: examination of several important conceptual models. For Ecol Manage 200:249-261

Looney CE, D'Amato AW, Fraver S et al (2016) Examining the influences of tree-to-tree competition and climate on size-growth relationships in hydric, multi-aged Fraxinus nigra stands. For Ecol Manage 375:238-248

Madrigal-González J, Ruiz-Benito P, Ratcliffe S et al (2016) Complementarity effects on tree growth are contingent on tree size and climatic conditions across Europe. Sci Rep 6:1-11

Madrigal-González J, Andivia E, Zavala MA et al (2018) Disentangling the relative role of climate change on tree growth in an extreme Mediterranean environment. Sci Total Environ 642:619-628

Maestre FT, Callaway RM, Valladares F, Lortie CJ (2009) Refining the stress-gradient hypothesis for competition and facilitation in plant communities. J Ecol 97:199-205

Marqués L, Madrigal-González J, Zavala MA et al (2018) Last-century forest productivity in a managed dry-edge Scots pine population: the two sides of climate warming. Ecol Appl 28:95-105

Martínez-Vilalta J, López BC, Adell N et al (2008) Twentieth century increase of Scots pine radial growth in NE Spain shows strong climate interactions. Glob Chang Biol 14:2868-2881

Masaki T, Mori S, Kajimoto T et al (2006) Long-term growth analyses of Japanese cedar trees in a plantation: neighborhood competition and persistence of initial growth deviations. J For Res $11: 217-225$

McDowell N, Pockman WT, Allen CD et al (2008) Mechanisms of plant survival and mortality during drought: why do some plants survive while others succumb to drought? New Phytol 178:719-739

McTague JP, Weiskittel AR (2016) Individual-tree competition indices and improved compatibility with stand-level estimates of stem density and long-term production. Forests 7:238

Oliver CD, Larson BC (1996) Forest stand dynamics. Updated edn. John Wiley and Sons

Pacala SW, Weiner J (1991) Effects of competitive asymmetry on a local density model of plant interference. J Theor Biol 149:165-179

Peel MC, Finlayson BL, Mcmahon TA et al (2007) Updated world map of the Köppen-Geiger climate classification. Hydrol Earth Syst Sci 11:1633-1644

Peñuelas J, Canadell JG, Ogaya R (2011) Increased water-use efficiency during the 20th century did not translate into enhanced tree growth. Glob Ecol Biogeogr 20:597-608

Pinheiro J, Bates D, DebRoy S, et al (2018) Linear and nonlinear mixed effects models. R Packag. version 3.1-137.

Piutti E, Cescatti A (1997) A quantitative analysis of the interactions between climatic response and intraspecific competition in European beech. Can J For Res 27:277-284

Pothier D (2017) Relationships between patterns of stand growth dominance and tree competition mode for species of various shade tolerances. For Ecol Manage 406:155-162

Pretzsch H, Dieler J (2010) The dependency of the size-growth relationship of Norway spruce (Picea abies [L.] Karst.) and European beech (Fagus sylvatica [L.]) in forest stands on longterm site conditions, drought events, and ozone stress. Trees 25:355-369

Primicia I, Artázcoz R, Imbert J-B et al (2016) Influence of thinning intensity and canopy type on Scots pine stand and growth dynamics in a mixed managed forest. For Syst 25:e057
Pukkala T, Kolström T (1987) Competition indices and the prediction of radial growth in Scots pine. Silva Fennica 21:55-67

R Core Team (2018) R: a language and environment for statistical computing. R Core Team, Vienna

Ruiz-Benito P, Lines ER, Gómez-Aparicio L et al (2013) Patterns and drivers of tree mortality in iberian forests: climatic effects are modified by competition. PLoS ONE 8(2):e56843

Ruiz-Labourdette D, Nogués-Bravo D, Ollero HS et al (2012) Forest composition in Mediterranean mountains is projected to shift along the entire elevational gradient under climate change. $\mathrm{J}$ Biogeogr 39:162-176

Ryan MG, Phillips N, Bond BJ (2006) The hydraulic limitation hypothesis revisited. Plant Cell Environ 29:367-381

Sack L (2004) Responses of temperate woody seedlings to shade and drought: do trade-offs limit potential niche differentiation? Oikos 107:110-127

Sánchez-Salguero R, Linares JC, Camarero JJ et al (2015) Disentangling the effects of competition and climate on individual tree growth: a retrospective and dynamic approach in Scots pine. For Ecol Manage 358:12-25

Sánchez-Salguero R, Camarero JJ, Gutiérrez E et al (2016) Assessing forest vulnerability to climate warming using a process-based model of tree growth: bad prospects for rear-edges. Glob Chang Biol 23:2705-2719

Schröter D, Cramer W, Leemans R et al (2005) Ecosystem service supply and vulnerability to global change in Europe. Science (80-) 310:1333-1337

Schwinning S, Weiner J (1998) Mechanisms the degree of size asymmetry determining in competition among plants. Oecologia 113:447-455

Sohn JA, Hartig F, Kohler M et al (2016) Heavy and frequent thinning promotes drought adaptation in Pinus sylvestris forests. Ecol Appl 26:2190-2205

Stadt K, Huston C, Coates KD, Zhili F, Dale MRT, Lieffers VJ (2007) Evaluation of competition and light estimation indices for predicting diameter growth in mature boreal mixed forests. Ann For Sci 64:477-490

Stephenson NL, Das AJ, Condit R et al (2014) Rate of tree carbon accumulation increases continuously with tree size. Nature 507:90-93

Stoll P, Weiner J, Schmid B (1994) Growth variation in a naturally established population of Pinus sylvestris. Ecology 75:660-670

Tatsumi S, Owari T, Mori AS (2016) Estimating competition coefficients in tree communities: a hierarchical Bayesian approach to neighborhood analysis. Ecosphere 7:e01273

Thornthwaite C (1948) An approach toward a rational classification of climate. Am Geogr Soc An 38:55-94

Travis JMJ, Brooker RW, Dytham C (2005) The interplay of positive and negative species interactions across an environmental gradient: insights from an individual-based simulation model Biol Lett 1:5-8

UNEP (1992) World Atlas of Desertification, UNEP. UNEP, London

Vilà-Cabrera A, Martinez-vilalta J, Vayreda J, Retana J (2011) Structural and climatic determinants of demographic rates of Scots pine forests across the Iberian Peninsula. Ecol Appl 21:1162-1172

Vilà-Cabrera A, Martínez-Vilalta J, Retana J (2014) Variation in reproduction and growth in declining Scots pine populations. Perspect Plant Ecol Evol Syst 16:111-120

Weber P, Bugmann H, Fonti P, Rigling A (2008) Using a retrospective dynamic competition index to reconstruct forest succession. For Ecol Manage 254:96-106

Weiner J (1990) Asymmetric competition in plant populations. Trends Ecol Evol 5:360-364

Wood SN (2017) Generalized additive models: an introduction with R, 2nd edn. CRC Press, Boca Raton 
Yoda K, Kira T, Ogawa H, Hozumi K (1963) Self-thinning in overcrowded pure stands under cultivated and natural conditions. J Biol Osaka City Univ 14:107-129

Zavala MA, Bravo De La Parra R (2005) A mechanistic model of tree competition and facilitation for Mediterranean forests: scaling from leaf physiology to stand dynamics. Ecol Modell 188:76-92

Zavala MA, Espelta JM, Retana J (2000) Constraints and trade-offs in Mediterranean plant communities: the case of mixed holm oak (Quercus ilex L)-Aleppo pine (Pinus halepensis Mill.) forests. Bot Rev 66:119-149
Zhang JW, Powers RF, Oliver WW, Young DH (2013) Response of ponderosa pine plantations to competing vegetation control in Northern California, USA: a meta-analysis. Forestry 86:3-11

Publisher's Note Springer Nature remains neutral with regard to jurisdictional claims in published maps and institutional affiliations. 